\title{
RESEARCH PAPER \\ Yacon potato propagation from herbaceous cuttings with different numbers of buds
}

\author{
Joab Luhan Ferreira Pedrosa ${ }^{1}$, Fábio Luiz de Oliveira ${ }^{1}$, Moises Zucoloto ${ }^{1}$, \\ Mateus Oliveira Cabral ${ }^{1}$, Ramon Amaro de $\mathrm{Sales}^{2}$ and Arnaldo Henrique de \\ Oliveira Carvalho ${ }^{3}$ \\ ${ }^{1}$ Departamento de Agronomia, Universidade Federal do Espírito Santo. Alto Universitário, s/n Guararema, \\ 29500-000 Alegre, Espírito Santo, Brazil. \\ ${ }^{2}$ Departamento de Fitotecnia, Universidade Federal de Viçosa. Viçosa, MG, Brazil. \\ ${ }^{3}$ Instituto Federal de Educação, Ciência e Tecnologia do Espírito Santo, Campus Ibatiba. ES, Brazil.
}

\begin{abstract}
J.L. Ferreira-Pedrosa, F.L. de-Oliveira, M. Zucoloto, M. Oliveira-Cabral, R. A. de-Sales, and A.H. de Oliveira-Carvalho. 2020. Yacon potato propagation from herbaceous cuttings with different numbers of buds. Int. J. Agric. Nat. Resour. The objective of this study was to evaluate yacon potato propagation from herbaceous cuttings with different numbers of buds. Therefore, an experiment was carried out in two phases. The first phase was carried out in a greenhouse with seedlings using a randomized complete block design with 40 replicates. The treatments consisted of varying the number of buds per cutting: two buds (T1), three buds (T2), or four buds (T3). The second phase was carried out in the field following a randomized complete block design with 4 replicates, and the treatments were the same as those used in the seedling phase. The following morphological characteristics were evaluated: number of leaves per plant, leaf area, plant height, stem diameter, number of stems per plant, leaf dry mass, stems, rhizophores, tuberous roots, and tuberous root yield. The physiological characteristics evaluated were the relative chlorophyll content (FCI - Falker chlorophyll index), net $\mathrm{CO}_{2}$ assimilation rate, leaf transpiration, stomatal conductance, internal $\mathrm{CO}_{2}$ concentration, water use efficiency and instantaneous carboxylation efficiency. It was observed that the seedlings from cuttings with 3 buds presented higher stomatal conductance $\left(g_{s}\right)$, which reflected their higher transpiration rates. The yacon potato presented the best vegetative and productive development when propagated by herbaceous cuttings with three buds.
\end{abstract}

Keywords: Asexual propagation, Asteraceae, Cutting, Smallanthus sonchifolius.

\section{Introduction}

Yacon potato is indigenous to the Andean region. In recent years, it has attracted significant inter-

Received May 13, 2019. Accepted Mar 17, 2020.

Corresponding author: joabhuhan@yahoo.com.br est due to having substances that are beneficial for human health, such as fructans, particularly inulin-type fructans and fructooligosaccharides (FOS) (Machado et al., 2019). These fructans can resist hydrolysis by the digestive enzymes of the human body and thus pass through the digestive tract without being metabolized, providing low 
energy content $\left(1.5 \mathrm{kcal} \mathrm{g}^{-1}\right)$ and performing functions similar to dietary fiber (Genta et al., 2009). Yacon potato is a prebiotic food with low calorie content that is suitable for people with diabetes and who are overweight (Sacramento et al., 2017).

Studies on yacon potato are mainly based on their potential as a functional and medicinal food (Delgado et al., 2013, Satoh et al., 2013). However, information on their agronomic management, propagation and plant physiology is scarce (Silva et al., 2018; Kamp et al., 2019).

In an agronomic context, potato propagation is a management phase for which there is a great need for information. The main way to propagate yacon is by its vegetative parts, which is due to the difficulty in obtaining viable botanical yacon seeds (Zardini et al., 1991).

In its place of origin, the plant is vegetatively propagated in two ways. The most traditional is to use pieces of the subterranean portion of the stem, called rhizophores. Cuttings of the aerial stems can also be used, but this method is less common. According to Seminario et al. (2003), vegetative propagation by cuttings should be studied, since it could be an alternative method for yacon propagation, and propagules can be obtained in half of the time required for the use of rhizophores.

In Brazil, yacon potato propagation in production areas has been done only from rhizophores weighing from 60 to $80 \mathrm{~g}$ (Vilhena et al., 2000). This has made it difficult to acquire propagation material for the expansion of commercial crops since the cost of rhizophores has increased, accompanying the expansion of the crop. This has contributed to the limitation of crop expansion, especially for farmers who wish to start cultivating yacon potato (Silva, 2018).

Thus, the use of cuttings of aerial stems in yacon potato propagation can be an alternative to the use of rhizophores, particularly when establishing new crops, due to the possibility of producing a larger number of seedlings in a shorter period as well as the advantage of expressing stronger genotypes.

To promote the use of vegetative stems as a material for yacon potato propagation, it is important to define an ideal number of buds. This number can be one of the factors that strongly stimulates root growth. This effect is related to the translocation of carbohydrates to the base of the cutting as well as to auxins, which are plant hormones that participate in plant growth and differentiation and other important cofactors for rooting (Taiz et al., 2017).

Therefore, the purpose of this study was to evaluate yacon potato propagation from herbaceous cuttings with different numbers of buds.

\section{Materials And Methods}

\section{Development of greenhouse seedlings}

An experiment was carried out in a commercial seedling production greenhouse from February to April 2017. The greenhouse is located in the municipality of Alegre/ES, at $20^{\circ} 47^{\prime} 1$ ' south latitude and $41^{\circ} 36^{\prime} 56^{\prime \prime}$ west longitude and 640 m altitude.

The experimental design was completely randomized with three treatments and 40 replicates. The treatments consisted of varying the number of buds per cutting: two buds (T1), three buds (T2), or four buds (T3).

The herbaceous cuttings were obtained from an experimental yacon crop grown in the Alto Norte municipality of Muniz Freire/ES (1180 m altitude). Afterwards, the plant material was taken to the plant analysis laboratory at the Federal University of Espírito Santo (CCAE-UFES) to prepare the cuttings.

The cuttings were cut with gardening secateurs and standardized to an average diameter of $15 \mathrm{~mm}$. 
The length varied according to the number of buds and to each treatment, with approximately $10 \mathrm{~cm}$ (T1), $13 \mathrm{~cm}$ (T2), and $15 \mathrm{~cm}$ (T3). Afterwards, to protect each cutting from a possible pathogen attack, the rhizophores were washed in running water and then immersed for 10 minutes in 5\% sodium hypochlorite solution (Seminário et al., 2003). Afterwards, they were disinfested in the apex-up position in a container with filtered water covering $1 / 3$ of the length of the cuttings until planting.

Planting was carried out the day after the cuttings were prepared (that is, two days after the cuttings were collected) in polyethylene bags (dimensions of $10 \mathrm{~cm}$ in diameter and $22 \mathrm{~cm}$ in height, with a volume capacity of 1.7 liters) filled with substrate consisting of soil + manure. The substrate included $100 \mathrm{mg} \mathrm{dm}^{-3} \mathrm{P}, 657 \mathrm{mg}$ $\mathrm{dm}^{-3} \mathrm{~K}, 4.74 \mathrm{cmol}_{\mathrm{c}} \mathrm{dm}^{-3} \mathrm{Ca}, 0.97 \mathrm{cmol}_{\mathrm{c}} \mathrm{dm}^{-3}$ $\mathrm{Mg}, 3.05 \mathrm{cmol}_{\mathrm{c}} \mathrm{dm}^{-3}$ of $\mathrm{H}+\mathrm{Al}$, and $7.67 \mathrm{~g} \mathrm{~kg}^{-1}$ of organic matter. The bags were kept under a "sombrite" screen (50\% light restriction) and irrigated twice daily with 13 liters (capacity/ volume) distributed evenly with a sprinkler to all the seedlings.

At 60 days after planting, the experiment was performed, and morphological and physiological analyses were performed. The morphological parameters evaluated were the average leaf area, number of shoots, number of fully developed leaves and diameter of the most developed bud. Additionally, the aerial and underground dry biomass were evaluated.

The leaf area was estimated according to the model of indirect determination $\left(\mathrm{AF}_{\mathrm{CL}}=(-27.7418\right.$ + (3.9812CL/ln CL) proposed by Erlacher et al. (2016) by measuring the width and length of each leaf. The diameter of the shoots was measured using a digital caliper. The dry biomass was dried in a forced circulation air oven at a temperature of $65{ }^{\circ} \mathrm{C}$ until the weight was stable. The biomass was determined using a digital scale.
The physiological parameters evaluated were the estimated net carbon assimilation rate, stomatal conductance, leaf transpiration rate, estimated water use efficiency, internal $\mathrm{CO}_{2}$ concentration, and instantaneous carboxylation efficiency. All experiments were carried out by an infrared gas reader (IRGA Liquor 6400XT).

These evaluations were performed on a clear day between 8 and 11 am on fully developed leaves without any type of visible anomaly. The photosynthetically active radiation was standardized in artificial saturating light of $1000 \mu \mathrm{mol}$ photons $\mathrm{m}^{-2} \mathrm{~s}^{-1}$ and $\mathrm{CO}_{2}$ at a concentration of $420 \mathrm{ppm}$.

The determination of the relative foliar chlorophyll $a, b$ and total content was carried out using a digital chlorophyll meter. The ClorofiLOG chlorophyll meter (CFL 1030 - Falker) uses emitting photodiodes in three wavelengths; two emit within the red band, close to the peaks of each type of chlorophyll ( $\lambda=635$ and $660 \mathrm{~nm}$ ), and the other emits in the near-infrared $(\lambda=880$ $\mathrm{nm}$ ). From these data, the device provides a value called the Falker chlorophyll index (FCI) that is proportional to the absorbance of the chlorophylls (Barbieri et al., 2012).

The data were submitted to analysis of variance by the F-test, and the means were compared by the Tukey test $(\mathrm{p}<0.05)$. The statistical analysis was performed using R software (Development Core Team 2016).

\section{Growth and production in the field}

To track the development of plants until harvest, an experiment was conducted from April to October 2017 in the experimental area of the CCAE/ UFES in the municipality of Alegre-ES at $20^{\circ} 45^{\prime}$, south latitude and $41^{\circ} 29^{\prime}$ 'west longitude and an altitude of $113 \mathrm{~m}$.

The area is a lowland region located in Rio Itapemirim that is characterized as a hot tropical 
microregion (lowlands) with higher temperatures (Pezzopane et al., 2012). The average monthly temperature varied from $22{ }^{\circ} \mathrm{C}$ to $26^{\circ} \mathrm{C}$, and the rainfall reached $201.6 \mathrm{~mm}$ during the months in which the experiment was conducted.

The soil where the experiment was conducted was classified as a Red-Yellow Latosol with sandy clay loam texture (Embrapa, 2014), and the samples were collected at a depth of 0-20 $\mathrm{cm}$. The samples were analyzed in the CCAE/ UFES Soils Laboratory, presenting the following values: $\mathrm{pH}$ (water) 5.73; phosphorus Mehlich ${ }^{-1}$ $\left(\mathrm{mg} \mathrm{dm}^{-3}\right) 34.79$; potassium $\left(\mathrm{mg} \mathrm{dm}^{-3}\right) 42$; calcium $\left(\mathrm{cmol}_{\mathrm{c}} \mathrm{dm}^{-3}\right)$ 2.51; magnesium $\left(\mathrm{cmol}_{\mathrm{c}} \mathrm{dm}^{-3}\right)$ 1.38; aluminum $\left(\mathrm{cmol}_{\mathrm{c}} \mathrm{dm}^{-3}\right)$ 0.00; sum of bases $\left(\mathrm{cmol}_{\mathrm{c}}\right.$ $\left.\mathrm{dm}^{-3}\right)$ 2.36; effective CEC $\left(\mathrm{cmol}_{\mathrm{c}} \mathrm{dm}^{-3}\right)$ 2.36; base saturation (\%) 57.34; total organic carbon (\%) 1.0; total nitrogen (\%) 0.1 ; sand (\%) 55; silt (\%) 4; and clay (\%) 30 .

The experiment was carried out in a randomized complete block design with four replications. The treatments consisted of the seedlings produced from the herbaceous cuttings with different types of buds: two buds (T1), three buds (T2), or four buds (T3). Each experimental plot consisted of 4 planting lines with 5 plants spaced $1.0 \mathrm{~m}$ between rows and $0.5 \mathrm{~m}$ between plants. The two central lines were considered the useful area, except the border plants of each row.

Fertilization management was carried out by applying $180 \mathrm{~g}$ of tanned bovine manure per plant. The bovine manure contained the following nutrients: 15.05 g. kg-1 of N; 6.00 g. kg-1 of P;

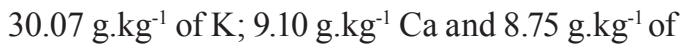
$\mathrm{Mg}$. Throughout the crop cycle, manual control of spontaneous plants and conventional sprinkler irrigation were performed after daily observation of soil water conditions, according to the recommendations for the cultivation of yacon potato (Quaresma, 2018).

During the vegetative cycle (60 to 220 days after transplanting - DAT), the plants were evaluated for morphological development: leaf area, number of leaves, plant height (highest stem), number of stems per plant and collar diameter. Additionally, physiological traits were evaluated: the chlorophyll $a$ and $b$ content and total leaf chlorophyll between 8 and $11 \mathrm{am}$.

At the end of the cycle (220 DAT), the leaf dry mass, rhizophores, tuberous roots and yield of fresh tuberous roots were evaluated as well as other physiological aspects of the plant, such as the estimated net carbon assimilation rate, stomatal conductance, leaf transpiration rate, estimated water use efficiency, internal $\mathrm{CO}_{2}$ concentration and instantaneous carboxylation efficiency.

The data were submitted to analysis of variance by the F-test, and the means were compared by the Tukey test $(\mathrm{p}<0.05)$. Regressions were also adjusted for the variables over time when significant. The statistical analysis was performed in R software (Development Core Team 2016).

\section{Results}

\section{Development of nursery seedlings}

The seedlings from cuttings of 2 or 3 buds showed the highest number of shoots, which was already expected. These shoots showed larger diameters than the seedlings from 4-bud cuttings. The seedlings originating from cuttings with 2 or 3 buds also showed a higher number of leaves and a greater leaf area per plant than the seedlings originating from 4-bud cuttings (Table 1). The more vigorous shoots (larger diameter) and larger leaves were reflected in the shoot dry mass accumulation, which was higher in the seedlings from cuttings with 2 or 3 buds and the higher root dry mass in seedlings from cuttings with 3 buds (Table 1).

It was found that there was no difference between treatments in terms of the relative chlorophyll $a$ content. The seedlings from cuttings with 3 
Table 1. Number of shoots, shoot diameter, number of leaves, leaf area and shoot and root dry mass in yacon potato seedlings from herbaceous cuttings with different numbers of buds.

\begin{tabular}{lcccccc}
\hline Treatment & NB & SD $(\mathrm{mm})$ & NL & LA $\left(\mathrm{cm}^{2}\right)$ & SDM $(\mathrm{g})$ & RDM $(\mathrm{g})$ \\
\hline T1 & $1.55 \mathrm{~b}$ & $6.77 \mathrm{to}$ & $9.05 \mathrm{~b}$ & $226.54 \mathrm{~b}$ & $2.22 \mathrm{a}$ & $0.16 \mathrm{c}$ \\
T2 & $1.44 \mathrm{~b}$ & $7.11 \mathrm{a}$ & $8.88 \mathrm{~b}$ & $248.80 \mathrm{a}$ & $2.21 \mathrm{a}$ & $0.24 \mathrm{a}$ \\
T3 & $1.83 \mathrm{a}$ & $6.08 \mathrm{~b}$ & $9.89 \mathrm{a}$ & $187.47 \mathrm{c}$ & $2.01 \mathrm{~b}$ & $0.19 \mathrm{~b}$ \\
$\mathrm{CV}(\%)$ & 28.39 & 11.42 & 10.15 & 6.55 & 8.24 & 12.31 \\
\hline
\end{tabular}

$\mathrm{T} 1=2$ buds; $\mathrm{T} 2=3$ buds; $\mathrm{T} 3=4$ buds, mean values in the column followed by the same letter do not differ by Tukey's test at $5 \%$ probability. Leaf area (LA), plant height (PH), shoot diameter (SD), leaf number (LN), shoot dry mass (SDM) and root dry mass (RDM).

buds had higher levels of chlorophyll $b$ and total chlorophyll, but the total chlorophyll did not differ from that in the seedlings from cuttings with 4 buds (Table 2).

Observing the physiological variables, it was observed that the seedlings from cuttings with 3 buds presented higher stomatal conductance $\left(g_{s}\right)$, which was reflected in their higher transpiration rates $(E)$. A higher net assimilation rate $(A)$ was also observed in the 3 buds seedlings, despite their statistical similarity with the 2 bud buds (Table 3). This reflects the greater efficiency of seedlings of 2 and 3 buds in increasing dry mass due to their leaf area, as already observed.

Table 2. Relative chlorophyll (FCI - Falker chlorophyll index) in yacon potato seedlings from herbaceous cuttings with different numbers of buds.

\begin{tabular}{lccc}
\hline Treatment & Chlorophyll $a$ & Chlorophyll $b$ & Total Chlorophyll \\
\hline T1 & $23.88^{\mathrm{ns}}$ & $6.72 \mathrm{~b}$ & $30.52 \mathrm{~b}$ \\
T 2 & $24.66^{\mathrm{ns}}$ & $7.23 \mathrm{a}$ & $31.89 \mathrm{a}$ \\
T 3 & $24.47^{\mathrm{ns}}$ & $6.22 \mathrm{c}$ & $30.69 \mathrm{ab}$ \\
CV (\%) & 3.6 & 6.19 & 3.84 \\
\hline
\end{tabular}

$\mathrm{T} 1=2$ buds; $\mathrm{T} 2=3$ buds; $\mathrm{T} 3=4$ buds. Mean values in the column followed by the same letter do not differ by Tukey's test at $5 \%$ probability, ${ }^{\text {ns }}$ not significant.

The seedlings from cuttings with 3 buds showed lower water use efficiency (WUE) and a higher internal $\mathrm{CO}_{2}$ concentration $\left(C_{i}\right)$ in the leaves (though the $C_{i}$ was similar to that in the seedlings from cuttings with 4 buds) than the other seedlings; therefore, the seedlings from cuttings with 3 buds also had greater stomatal conductance $(g)$ than the other seedlings. In terms of instantaneous carboxylation efficiency $\left(A / C_{i}\right)$, the cuttings with 2 or 3 buds had the highest values (Table 3 ).

\section{Field seedling development}

Yacon potato plants show an increasing number of leaves during their growth cycle, and the plants from cuttings with 3 buds (T2) showed the greatest number of leaves (Figure 1a). The leaf area also increased during the growth cycle, with T2 plants presenting larger leaf areas at the beginning of the cycle. However, after 160 DAP, the $\mathrm{T} 2$ plants had reduced their investment in leaf area expansion (Figure 1b).

The highest relative levels of total chlorophyll and chlorophyll $a$ and $b$ occurred in plants from cuttings with 3 buds, followed by those in seedlings from cuttings with 4 buds, for most of the cycle. The peak chlorophyll activity in all plants occurred at approximately 160 DAT (Figure 2).

The plants from cuttings with 3 buds (T2) also presented the highest rate of net carbon assimilation $(A)$, stomatal conductance $\left(g_{s}\right)$, transpiration $(E)$ and instantaneous carboxylation efficiency $\left(A / C_{i}\right)$ (Table 4). There were no significant differences 

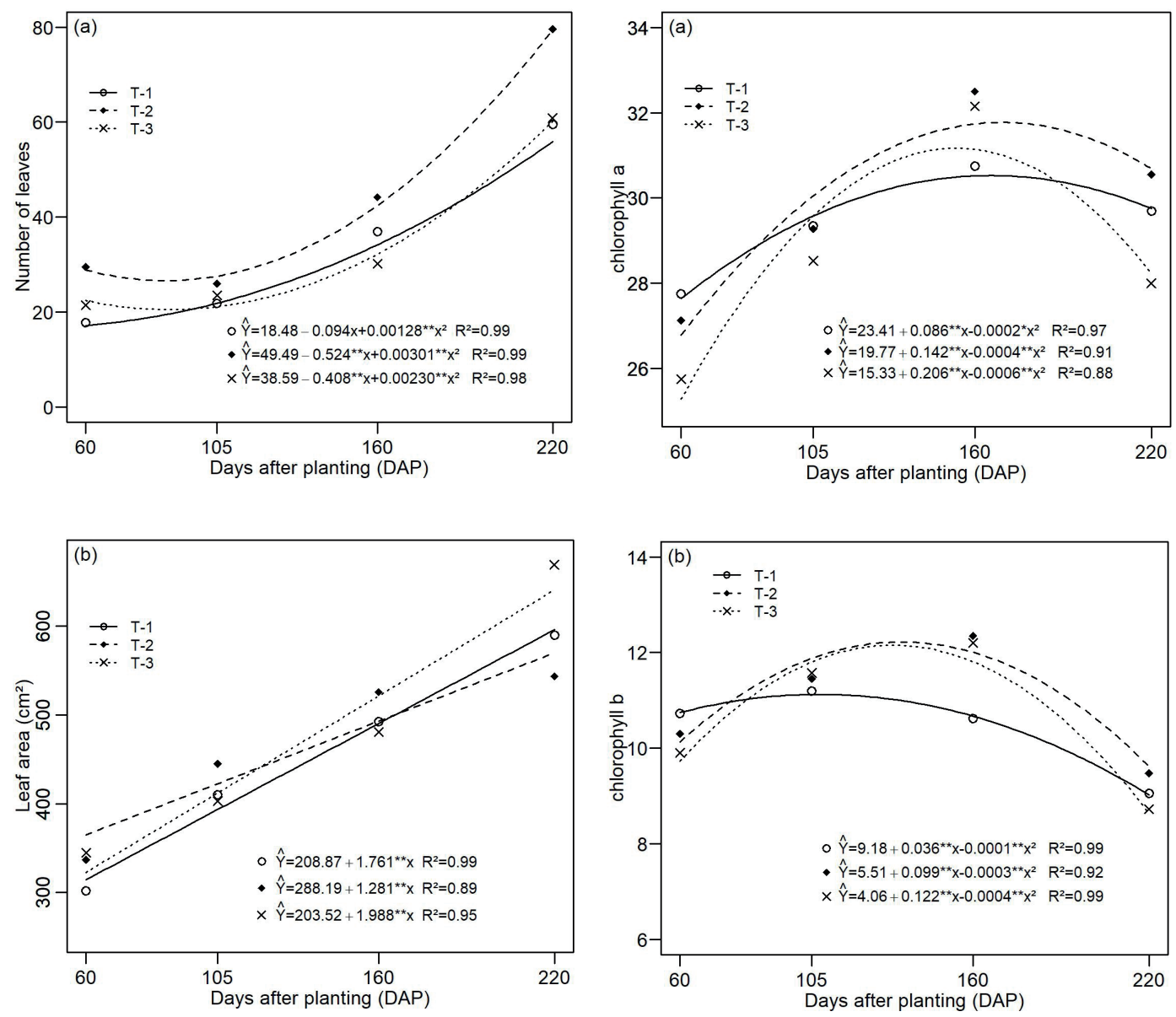

Figure 1. Number of leaves (a) and leaf area (b) in yacon potato plants from herbaceous cuttings with different numbers of buds. $\mathrm{T} 1=2$ buds; $\mathrm{T} 2=3$ buds; $\mathrm{T} 3=4$ buds. Significant at $* \mathrm{p}<0.05 ; * * \mathrm{p}<0.01$.

between treatments in terms of instantaneous water use efficiency ( $W U E$ ) or internal $\mathrm{CO}_{2}$ concentration $\left(C_{i}\right)$ (Table 4). T2 plants presented the highest values for the instantaneous efficiency of carboxylation $\left(A / C_{i}\right)$ (Table 4$)$.

The T2 plants presented greater accumulations of shoot dry matter, rhizophores and roots (Table 5). The highest total productivity of tuberous roots occurred in these plants (T2), followed by that in T3 plants (seedlings from cuttings with 4 buds) (Table 5), corroborating the good development observed in these plants.

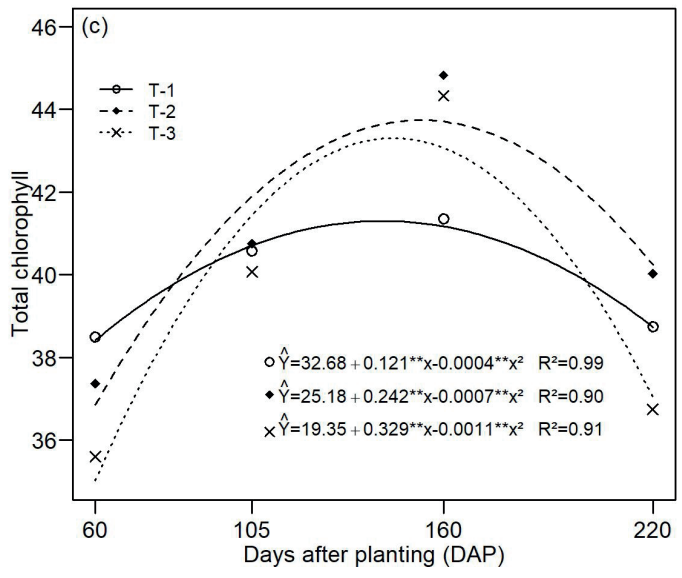

Figure 2. Relative chlorophyll (FCI - Falker chlorophyll index) $a$ (a) and $b$ (b) and total chlorophyll (c) content in yacon potato plants from herbaceous cuttings with different numbers of buds. $\mathrm{T} 1=2$ buds; $\mathrm{T} 2=3$ buds; $\mathrm{T} 3=4$ buds. Significant at $* \mathrm{p}<0.05 ; * * \mathrm{p}<0.01$. 
Table 3. Stomatal conductance, transpiration, net $\mathrm{CO}_{2}$ assimilation rate, water use efficiency, internal $\mathrm{CO}_{2}$ concentration and instantaneous carboxylation efficiency in leaves of yacon potato seedlings from herbaceous cuttings with different numbers of buds.

\begin{tabular}{lccc}
\hline Treatment & $g_{s}\left(\mathrm{~mol} \mathrm{H}_{2} \mathrm{O} \mathrm{m}^{-2} \mathrm{~s}^{-1}\right)$ & $E\left(\mathrm{mmol} \mathrm{H}_{2} \mathrm{O} \mathrm{m}^{-2} \mathrm{~s}^{-1}\right)$ & $A\left(\mu \mathrm{mol} \mathrm{CO}_{2} \mathrm{~m}^{-2} \mathrm{~s}^{-1}\right)$ \\
\hline $\mathrm{T} 1$ & $0.513 \mathrm{c}$ & $2.23 \mathrm{c}$ & $5.53 \mathrm{ab}$ \\
$\mathrm{T} 2$ & $0.777 \mathrm{a}$ & $4.37 \mathrm{a}$ & $5.59 \mathrm{a}$ \\
$\mathrm{T} 3$ & $0.695 \mathrm{~b}$ & $3.69 \mathrm{~b}$ & $5.38 \mathrm{~b}$ \\
$\mathrm{CV}(\%)$ & 7.68 & 6.34 & 5.63 \\
\hline \multirow{2}{*}{ Treatment } & WUE $\left(\mu \mathrm{mol} \mathrm{CO}_{2} \mathrm{mmol}^{-1} \mathrm{H}_{2} \mathrm{O}\right)$ & $C_{i}\left(\mu \mathrm{mol} \mathrm{CO}_{2} \mathrm{~m}^{-2} \mathrm{~s}^{-1}\right)$ & $A C_{i}\left(\mu \mathrm{mol} \mathrm{CO}_{2} \mathrm{~m}^{-1} \mathrm{~s}^{-1 /}\right.$ \\
T-1 & $2.48 \mathrm{a}$ & $338.23 \mathrm{~b}$ & $\left.\mu \mathrm{mol}_{2} \mathrm{~mol}^{-1}\right)$ \\
T-2 & $1.28 \mathrm{c}$ & $370.30 \mathrm{a}$ & $0.016 \mathrm{a}$ \\
$\mathrm{T}-3$ & $1.45 \mathrm{~b}$ & $361.63 \mathrm{a}$ & $0.015 \mathrm{a}$ \\
$\mathrm{CV}(\%)$ & 7.5 & 4.47 & $0.013 \mathrm{~b}$ \\
\hline
\end{tabular}

$\mathrm{T} 1=2$ buds; $\mathrm{T} 2=3$ buds; $\mathrm{T} 3=4$ buds. Mean values in the column followed by the same letter do not differ by Tukey's test at $5 \%$ probability. Stomatal conductance $\left(g_{s}\right)$ transpiration $(E)$, liquid absorption rate of $\mathrm{CO}_{2}(A)$, water use efficiency $(W U E), \mathrm{CO}_{2}$ internal concentration $\left(C_{i}\right)$ and instantaneous carboxylation efficiency $\left(A / C_{i}\right)$.

Table 4. Stomatal conductance, transpiration, net $\mathrm{CO}_{2}$ assimilation rate, water use efficiency, internal $\mathrm{CO}_{2}$ concentration and instantaneous carboxylation efficiency in leaves of yacon potato seedlings from herbaceous cuttings with different numbers of buds.

\begin{tabular}{lccc}
\hline Treatment & $g_{s}\left(\mathrm{~mol} \mathrm{H}_{2} \mathrm{O} \mathrm{m}^{-2} \mathrm{~s}^{-1}\right)$ & $E\left(\mathrm{mmol} \mathrm{H}_{2} \mathrm{O} \mathrm{m}^{-2} \mathrm{~s}^{-1}\right)$ & $A\left(\mu \mathrm{mol} \mathrm{CO}_{2} \mathrm{~m}^{-2} \mathrm{~s}^{-1}\right)$ \\
\hline $\mathrm{T} 1$ & $0.47 \mathrm{~b}$ & $2.89 \mathrm{~b}$ & $12.80 \mathrm{~b}$ \\
$\mathrm{~T} 2$ & $0.62 \mathrm{a}$ & $3.46 \mathrm{a}$ & $16.20 \mathrm{a}$ \\
$\mathrm{T} 3$ & $0.48 \mathrm{~b}$ & $2.50 \mathrm{~b}$ & $13.89 \mathrm{~b}$ \\
$\mathrm{CV}(\%)$ & 5.43 & 6.82 & 5.69 \\
\hline Treatment & $W U E\left(\mu \mathrm{mol} \mathrm{CO} \mathrm{mmol}^{-1} \mathrm{H}_{2} \mathrm{O}\right)$ & $C_{i}\left(\mu \mathrm{mol} \mathrm{CO}_{2} \mathrm{~m}^{-2} \mathrm{~s}^{-1}\right)$ & $A C_{i}\left(\mu \mathrm{mol} \mathrm{CO}_{2} \mathrm{~m}^{-1} \mathrm{~s}-1\right.$ \\
\hline T1 & $4.80^{\mathrm{ns}}$ & $442.50^{\mathrm{ns}}$ & $\left.\mathrm{Mmol} \mathrm{CO}_{2} \mathrm{~mol}^{-1}\right)$ \\
$\mathrm{T} 2$ & $4.68^{\mathrm{ns}}$ & $443.75^{\mathrm{ns}}$ & $0.31 \mathrm{~b}$ \\
$\mathrm{~T} 3$ & $5.14^{\mathrm{ns}}$ & $433.25^{\mathrm{ns}}$ & $0.36 \mathrm{a}$ \\
$\mathrm{CV}(\%)$ & 9.47 & 2.57 & $0.29 \mathrm{c}$ \\
\hline
\end{tabular}

$\mathrm{T}-1=2$ buds; $\mathrm{T} 2=3$ buds; $\mathrm{T} 3=4$ buds. Mean values in the column followed by the same letter do not differ by Tukey's test at $5 \%$ probability; ${ }^{\text {ns }}$, not significant. Stomatal conductance $\left(g_{s}\right)$ transpiration $(E)$, liquid absorption rate of $\mathrm{CO}_{2}$ $(A)$, water use efficiency $(W U E), \mathrm{CO}_{2}$ internal concentration $\left(C_{i}\right)$ and instantaneous carboxylation efficiency $\left(A / C_{i}\right)$.

Table 5. Shoot, rhizophore and root dry mass, and total yield of fresh roots of yacon potato plants from herbaceous cuttings with different numbers of buds.

\begin{tabular}{lcccc}
\hline Treatments & Shoot dry mass $\left(\mathrm{t} \mathrm{ha}^{-1}\right)$ & Rhizophore dry mass $\left(\mathrm{t} \mathrm{ha}^{-1}\right)$ & Root dry mass $\left(\mathrm{t} \mathrm{ha}^{-1}\right)$ & Total yield(t ha-1 $)$ \\
\hline T1 & $1.91 \mathrm{ab}$ & $0.95 \mathrm{~b}$ & $1.95 \mathrm{~b}$ & $25.1 \mathrm{c}$ \\
$\mathrm{T} 2$ & $2.20 \mathrm{a}$ & $1.65 \mathrm{a}$ & $2.95 \mathrm{a}$ & $42.8 \mathrm{a}$ \\
$\mathrm{T} 3$ & $1.73 \mathrm{~b}$ & $1.05 \mathrm{~b}$ & $2.25 \mathrm{ab}$ & $32.8 \mathrm{~b}$ \\
$\mathrm{CV} \%$ & 9.67 & 14.78 & 8.22 & 8.17 \\
\hline
\end{tabular}

$\mathrm{T}-1=2$ buds; $\mathrm{T} 2=3$ buds; T3=4 buds. Means in the column followed by the same letter do not differ by Tukey's test at $5 \%$ probability. 


\section{Discussion}

\section{Development of nursery seedlings}

The results showed a possible offsetting effect in the seedlings because the seedlings from cuttings with 2 or 3 buds, despite having a lower number of shoots and leaves, had more vigorous shoots (larger diameters). Additionally, the larger plant leaf area indicated a greater investment in shoot vigor and leaf expansion.

A larger leaf area is an interesting feature because it represents a greater capacity for photoassimilate production, which is reflected in the greater dry mass accumulation in these seedlings. It also may increase auxin synthesis since young leaf tissues are important sites of this hormone, which is essential for adventitious root emission and plant growth (Carvalho et al., 2015). This led to the greater root dry mass accumulation in the seedlings from cuttings with 3 buds.

The balance between the shoot and root dry weight in the seedlings from cuttings with 3 buds led to the best investment in roots and improved the seedling quality. This relationship is of fundamental importance for the organization and functioning of the physiological processes and for plant development, where the root is the energy source and the aerial part is a drain on the organic reserves (Barros et al., 2017).

The higher mass accumulation in the seedlings from cuttings with 3 buds is related to the physiological behavior of these plants. They showed greater photosynthetic efficiency, mainly in light absorption and in the transfer of radiant energy to the reaction centers, due to their higher amounts of chlorophyll b (Streit et al., 2005).

The higher photosynthetic efficiency in these seedlings ( 3 buds) is shown by the higher net assimilation rates of $\mathrm{CO}_{2}(A)$, which can be related to their more comfortable condition (possibly due to the better balance in the photoassimilate source/drain ratio), which would allow the maintenance of the soil-plant-atmosphere continuum (Paul et al., 2017).

The maintenance of the soil-plant-atmosphere continuum was due to the greater stomatal conductance $(g)$ presented by these seedlings ( 3 buds), which also led to higher transpiration rates $(E)$, consequently resulting in greater water loss and reduced water use efficiency ( $W U E$ ). However, despite the lower water use efficiency for carbon fixation, this condition did not affect seedling growth because the internal concentration of $\mathrm{CO}_{2}\left(C_{i}\right)$ in the substomatal chamber was higher in these plants; this allowed a greater instantaneous carboxylation efficiency $\left(A / C_{i}\right)$ since these two variables have a close and interconnected relationship (Machado et al., 2005).

This shows that there was a positive balance between $\mathrm{CO}_{2}$ fixation in photosynthesis and respiration $\mathrm{CO}_{2}$ release. Possibly due to the $C_{i}$ in the seedlings (3 buds), RuBisCO (ribulosebisphosphatecarboxylase-1,5-oxigenasse) was not saturated and worked efficiently, promoting a linear increase in the net assimilation rate $(A)$, as explained by (Zeist et al. 2017).

Thus, the development of seedling $g s$ from herbaceous cuttings with 3 buds showed superior morphological and physiological results, indicating that this would be the best option for seedling production from herbaceous cuttings.

\section{Field seedling development}

Plants from herbaceous cuttings with 3 buds (T2) presented the best vegetative performance in the field due to the strong development of the seedlings produced with herbaceous cuttings with 3 buds in the greenhouse.

T2 plants presented a higher number of leaves than the other plants, which, together with the larger leaf area at the beginning of the cycle, allowed 
greater photosynthetic efficiency, mainly due to the greater interception of canopy light during the growth cycle (Pinzón \& Schiavinato, 2008). Consequently, higher photoassimilate production capacity allowed the plants to increase storage in their tuberous roots, which are strong photoassimilate drains to the detriment of leaf expansion (Tardieu, 2013). This result was observed at the end of the crop cycle, when these plants reduced their investment in leaf area expansion but presented higher tuberous root production, which is directly related to the production capacity of the crop.

The results of the relative chlorophyll content analysis corroborate the interpretation that the $\mathrm{T} 2$ plants were in better physiological conditions, having a greater ability to perform photosynthesis and a higher capacity for light absorption than the other plants. This occurred as a result of the higher total chlorophyll content and the transfer of radiant energy to the reaction centers (higher chlorophyll $b$ content) (Streit et al.,2005).

The peak chlorophyll activity that occurred at approximately 160 DAT may have been related to the tanned bovine manure $\left(1.62 \mathrm{~kg}\right.$ of $\left.\mathrm{N} \mathrm{ha}^{-1}\right)$ fertilization applied at 105 DAT, which may have led to higher values of chlorophyll in the following evaluation (160 DAT). This increase may have been due to the higher availability of nutrients such as nitrogen and magnesium, considering that these elements are constituents of the chlorophyll molecule (Armond et al., 2016).

In general, from $160 \mathrm{DAT}$, all yacon plants showed a decrease in chlorophyll content due to the increase in the average age of the leaves (Pohl et al., 2009), as well as the natural senescence of the plant from that point (Silva et al., 2018). In addition, this result may be due to canopy shading, which becomes stronger at this stage of crop development (Silva et al., 2018), consequently reducing the chlorophyll activity in the leaves (Pohl et al., 2009).

Gas exchange analysis was performed on the plants from seedlings from cuttings with 3 buds (T2), and they presented greater assimilate production capacity than the other seedlings due to their increased liquid absorption rate of $\mathrm{CO}_{2}(A)$. This is related to the highest stomatal conductance $\left(g_{s}\right)$ and transpiration $(E)$ noted in these plants.

As a consequence of the higher net $\mathrm{CO}_{2}$ assimilation rates, the $\mathrm{T} 2$ plants presented higher instantaneous carboxylation efficiency $\left(A / C_{i}\right)$, since these factors have a close relationship (Machado et al., 2005).

The similar water use efficiency (WUE) among plants was due to the water demand of the crop having been adequately supplied. Thus, the plants were in equivalent condition to assimilate the same amounts of carbon per unit of water transpired via stomatal flow.

The internal carbon concentration $\left(C_{i}\right)$ may have remained stable in all plants because they balanced $\mathrm{CO}_{2}$ influx to the substomatal cavity with water efflux by transpiration, keeping $C_{i}$ approximately constant (Shimazaki et al., 2007).

The best physiological conditions, as presented in the T2 plants (from herbaceous cuttings with 3 buds), were reflected in their larger aerial part, and rhizophores and root dry mass accumulation than those in the other plants, indicating the potential of this form of propagation.

The higher mass accumulations in the tuberous roots presented by the T2 plants were reflected in their higher total fresh root productivity (42.8 $\left.\mathrm{t} \mathrm{ha}^{-1}\right)$. It is important to explain that yacon has shown great variation in terms of productive yield in tuberous roots. Studies have shown that yields vary from 25.6 to $119 \mathrm{t} \mathrm{ha}^{-1}$ of tuberous roots in several countries, such as Korea, the Czech Republic and the United States (Sumiyanto et al., 2012). There is also variation within Brazil. Silva et al. (2019) observed $97.50 \mathrm{t} \mathrm{ha}^{-1}$ (in mountainous conditions) and $60.65 \mathrm{t} \mathrm{ha}^{-1}$ (in the production of the lowland region) production, all produced 
from rhizophores as the propagation material. This variation is a consequence of cultivation conditions (climate and soil), crop management (including propagation material) and genetic variability (Sumiyanto et al., 2012).

The main conclusions are as follows. The herbaceous cuttings with 3 buds presented the best performance in the seedling and field phases, and this form of propagation is applicable to yacon cultivation.

\section{Acknowledgments}

The authors are grateful to Fundação de Amparo à Pesquisa do Espírito Santo (FAPES, Vitória-ES, Brazil) and Conselho Nacional de Desenvolvimento Científico e Tecnológico (CNPq, Brasília-DF, Brazil) for their financial support and granting scholarships and research. To Coordenação de Aperfeiçoamento de Pessoal de Nível Superior (CAPES, Brasília-DF, Brazil) for the master's scholarship to the first author.

\section{Resumen}

J.L. Ferreira-Pedrosa, F.L. de-Oliveira, M. Zucoloto, M. Oliveira-Cabral, R. A. de-Sales, y A.H. de Oliveira-Carvalho. 2020. Propagación de papa Yacon a partir de esquejes herbáceos con diferente número de yemas. Int. J. Agric. Nat. Resour. El objetivo de este estudio fue evaluar la propagación de papas yacón a partir de esquejes herbáceos con diferentes números de yemas. El experimento se llevó a cabo en dos fases. La primera fase se desarrolló en invernadero para plantas de semillero utilizando un diseño de bloques completos al azar con 40 repeticiones. Los tratamientos consistieron en variaciones del número de yemas por corte: a) T1- dos yemas; b) T2- tres yemas; c) T3- cuatro yemas. La segunda fase se llevó a cabo en campo siguiendo un diseño de bloques completos al azar, con 4 repeticiones, $\mathrm{y}$ los tratamientos fueron los mismos que en la fase de plántula. Se evaluaron las siguientes características morfológicas: número de hojas por planta, área foliar, altura de la planta, diámetro del tallo, número de tallos por planta, masa seca de la hoja, tallos, rizóforos e raíces tuberosas, rendimiento de la raíz tuberosa. Características fisiológicas: contenido relativo de clorofila (FCI - Clorofila Falker Index), tasa neta de asimilación de $\mathrm{CO}_{2}$, transpiración foliar, conductancia estomática, concentración interna de $\mathrm{CO}_{2}$, eficiencia de uso del agua y eficiencia de carboxilación instantánea. Se observó que las plántulas de esquejes con 3 yemas presentaban una conductancia estomática $\left(\mathrm{g}_{\mathrm{s}}\right)$ más alta y que reflejaban las tasas más altas de transpiración. La papa yacón presentó el mejor desarrollo vegetativo y productivo cuando se propagó por esquejes herbáceos con tres yemas.

Palabras clave: Asteraceae, estaca, propagación assexual, Smallanthuss sonchifolius. 


\section{References}

Armond, C., Oliveira, V.C., Gonzales, S.D.P., Oliveira, F.É.R., Silva, R.M., Leal T, T., \& Silva, F. (2016). Desenvolvimento inicial de plantas de abobrinha italiana cultivada com húmus de minhoca. Horticultura Brasileira, 34(3):439-442. doi: 10.1590/s0102-05362016003022

Barros, A.C.C.D., Almeida, J.C.D.C., Camargo, F.S.T., Carvalho, C.A.B.D., Campana, L.L., \& Morais, L.F.D. (2017). Root dry matter mass and distribution of Floricograss under different grazing strategies. Pesquisa Agropecuária Brasileira, 52(12):1276-1285. doi: 10.1590/s0100$204 \times 2017001200017$

Barbieri, J. É., Rossiello, R. O. P., Silva, R.V. M. M., Ribeiro, R.C., \& Morenz, M. J. (2012). Um novo clorofilômetro para estimar os teores de clorofila em folhas do capim Tifton 85. Ciência Rural,42(12):2242-2245. doi:10.1590/s010384782012005000109

Carvalho, J.S.B., Nunes, M.F.P.N., Campos, G.P.A., \& Goes, M.D.C.C. (2015). Influência de diferentes tipos de estacas e substratos na propagação vegetativa de Hyptispectinata. Revista de Ciências Agroveterinárias, 14(1):89-91.

Delgado, G.T.C., Tamashiro, W.M.D.S.C., Junior, M.R.M., \& Pastore, G.M. (2013). Yacon (Smallanthus sonchifolius): A Functional Food. Plant Foods for Human Nutrition, 68(3):222-228. doi:10.1007/s11130-013-0362-0

Empresa Brasileira de Pesquisa Agropecuária- EMBRAPA. (2014). Centro Nacional de Pesquisa de Solos. Sistema brasileiro de classificação de solos. Rio de Janeiro: 306 p.

Erlacher, W.A., Oliveira, F.L., Fialho, G.S., Silva, D.M.N., \& Carvalho, A.H.O. (2016). Models for estimating leaf área of yacon. Horticultura Brasileira, 34:422-427. doi:10.1590/S0102-05362016003019

Genta, S., Cabrera, W., Habib, N., Pons, J., Carillo, I.M., Grau, A., \& Sánchez, S. (2009). Yacon syrup: Beneficial effects on obesity and insulin resistance in humans. Clinical Nutrition, 28(2):182-187. doi: 10.1016/j.clnu.2009.01.013.

Kamp, L., Hartung, J., Mast, B., \& Graeff, H.S. (2019). Plant growth, tuber yield formation and costs of three different propagation methods of yacon (Smallanthus sonchifolius). Industrial Crops and Products, 132: 1-11. doi: 10.1016/j. indcrop.2019.02.006.

Machado, A.M., Silva, N.B., Chaves, J.B.P., \& Rita, C.G.A. (2019). Consumption of yacon flour improves body composition and intestinal function in overweight adults: A randomized, doubleblind, placebo-controlled clinical trial. Clinical Nutrition Espen, 29:22-29. doi: 10.1016 / j. clnesp.2018.12.082

Machado, E.C., Schmidt, P.T., Medina, C.L., \& Ribeiro, R.V. (2005). Respostas da fotossíntese de três espécies de citros a fatores ambientais. Pesquisa agropecuária brasileira, 40(12):1161-1170. doi: 10.1590/S0100204X2005001200002

Paul, S., Das, M.K., Baishya, P., Ramtek, E.A., Farooq, M., Baroowa, B., \& Gogoi, N. (2017). Effect of high temperature on yield associated parameters and vascular bundle development in five potato cultivars. Scientia Horticulturae 225:134140. doi: 10.1016/j.scienta.2017.06.061

Pezzopane, J.E.M, Castro, F.S., Pezzopane, J.R.M., \& Cecílio, R.A. (2012). Agrometeorologia: aplicações para o Espírito Santo. ES, 1. ed. 178 p.

Pinzón, T.J.A., \& Schiavinato, M.A. (2008). Crescimento, eficiência fotossintética e eficiência do uso da água em quatro espécies de leguminosas arbóreas tropicais. Hoehnea, 35(3):395-404. doi: 10.1590/s2236-89062008000300007

Pohl, S., Lopes, N.F., Braga, E.J.B., Silva, C.P., Silva, F.S.P., \& Peters, J.A. (2009). Características de crescimento de plantas de batata, cv. Baronesa, e seu genótipo transformado geneticamente para resistência ao PVY. Revista Ceres, 56:736-743.

Quaresma, M.A.L. (2018). Estratégias para cultivo de yacon: conservação de rizóforos, métodos $e$ profundidades de plantio em diferentes altitudes (Doutorado Tese em Produção Vegetal - Fitotecnia). Alegre - ES: Universidade Federal do Espírito Santo; $78 \mathrm{p}$.

R Development Core Team R. (2016). A language and environment for statistical computing. $R$ Foundation for Statistical Computing. Retrieved from http://www.R-project.org. 
Sacramento, M.S., Silva, P.S.R.C., \& Tavares, M.I.B. (2017). Batata yacon - alimento funcional. Semioses. 11(3):43-47. doi: 10.15202/1981996x. $2017 \mathrm{v} 11 \mathrm{n} 3 \mathrm{p} 43$

Satoh, H., Nguyen, M.A., Kudoh, A., \& Watanabe, T. (2013). Yacon diet (Smallanthus sonchifoliu) improves hepatic insulin resistance via reducing Trb3 expression in Zuckerfa/fa rats. $\mathrm{Nu}$ trition \& Diabetes, 3(5):70-75. doi:10.1038/ nutd.2013.11

Seminario J.M., Valderrama, E.I., \& Manrique, I. (2003). El yacón: fundamentos para el aprovechamiento de un recurso promisorio. Centro Internacional de la Papa (CIP), Universidad Nacional de Cajamarca, Agencia Suiza para el Desarrollo y la Cooperación (COSUDE), Lima, PER. 60p.

Shimazaki, K.I., Doi, M., Assmann, S.M., \& Kinoshita T. (2007). Light regulation of stomatal movement. Plant Biol, 58:219-247. doi: 10.1146/annurev.arplant.57.032905.105434

Silva, D.M.N., Oliveira F, L, Quaresma, M.A.L, \& Mendes, T.P. (2019). Yacon production for different planting seasons and growing conditions. Bioscience Journal, 35(2):1-12.

Silva, D.M.N., Venturim, C.H.P., Capucho, M.E.O.V, Oliveira, F.L., \& Mendonça, S.E. (2018). Impact of soil cover systems on soil quality and organic production of yacon. Scientia Horticulturae, 235:407-412. doi:10.1016/j.scienta.2018.03.024

Silva, D. M. N. D., Oliveira, F. L. D., Cavatte, P. C., Quaresma, M. A. L., \& Christo, B. F. (2018). Growth and development of yacon in different periods of planting and growing regions. Acta Scientiarum, 40(1):327-345. doi:10.4025/acta sciagron. v.40i1.39442

Streit, N.M., Canterle, L.P., Canto, M.W.D., \& Hecktheuer, L.H.H. (2005). The chlorophylls. Ciência Rural, 35(3):748-755. doi:10.1590/S010384782005000300043

Sumiyanto, J., Dayan, F.E., Cerdeira, A.L., Wang, Y.H., Khan, I.A., \& Moraes R.M. (2012). Oligofructans content and yield of yacon (Smallanthus sonchifolius) cultivated in Mississippi. Scientia Horticulturae, 148:83-88. doi:10.1016/j.scienta.2012.09.020

Taiz, L., Zeiger, E., Moller, I.M., \& Murphy, A. (2017). Fisiologia e desenvolvimento vegetal. 6. ed. Porto Alegre: Artme; 888 p.

Tardieu, F. (2013). Plant response to environmental conditions: assessing potential production, water demand, and negative effects of water deficit. Frontiers In Physiology, 4:1-12.

Vilhena, S.M.C., Câmara, F.L., \& Kakihara, S.T. (2000). O cultivo de yacon no Brasil. Horticultura Brasileira, 18(1):5-8. doi:10.1590/s010205362000000100002

Zardini, E. (1991). Ethnobotanical notes on "yacon", Polymnia sonchifolia (Asteraceae). Economic Botany, 45 (1):72-85.

Zeist, A.R., Piva, R., Resende, J. T., Silva, I, F., Athanázio, J.C., \& Rodrigues, J.D. (2017). Physiological and agronomic traits of cabbage plants hybrid Fuyutoyo sprayed with plant growth regulators. Horticultura Brasileira,35(2):210-215. doi:10.1590/s0102-053620170209 